\title{
Final internal cooking temperature of pork chops influenced consumer eating experience more than visual color and marbling or ultimate $\mathrm{pH}$
}

\author{
Lauren T. Honegger, Elaine Richardson, Emily D. Schunke, Anna C. Dilger, and Dustin D. Boler ${ }^{1}$ \\ Department of Animal Sciences, University of Illinois, Urbana, IL 61801
}

\begin{abstract}
The objective was to determine the effect of "quality grade" (combination of visual color and marbling) or ultimate $\mathrm{pH}$ on consumer eating experience of pork chops cooked to different final internal temperatures. The hypothesis was that consumers would rate a greater percentage of pork chops as acceptable when graded "choice," had a greater ultimate $\mathrm{pH}$, or when cooked to $63{ }^{\circ} \mathrm{C}$ compared with chops graded "standard," had a lesser ultimate $\mathrm{pH}$, or when cooked to 71 or $82{ }^{\circ} \mathrm{C}$. Consumers $(264$ total) were served chops in 1 of 2 experiments. Chops in Exp. 1 were classified as "choice" when NPPC visual color score $\geq 3$ and visual marbling score was $\geq 2$ or "standard" when NPPC scores did not meet the qualifications for "choice" and were cooked to either 63 or $71{ }^{\circ} \mathrm{C}$. Chops in Exp. 2 were categorized as high $\mathrm{pH}(5.88$ to 6.23$)$ or low pH (5.36 to 5.56) and cooked to 63,71 , or $82{ }^{\circ} \mathrm{C}$. Chops were cooked with a sous-vide device (ANOVA Precision Cooker, Anova Applied Electronics, San Francisco, CA) in a water bath. Consumers used a 9-point Likert-type score
\end{abstract}

system where scores 1 through 3 were considered not tender, not juicy, not flavorful, or unacceptable. Scores 4 through 6 were consider neutral for tenderness, juiciness, flavor, and overall acceptability. Scores 7 through 9 were considered tender, juicy, flavorful, and acceptable. Data were organized as a percentage of responses and analyzed using the GLIMMIX procedure of SAS for both experiments with models including treatment (quality grade, ultimate $\mathrm{pH}$, and final internal temperature) and all interactions. Quality grade did not affect $(P \geq 0.30)$ consumer ratings for any sensory trait. More $(P<0.01)$ consumers rated chops with a high $\mathrm{pH}(36.07 \%)$ as juicy compared with chops with a low pH $(24.29 \%)$, but $\mathrm{pH}$ category did not alter $(P \geq 0.13)$ perceptions for tenderness, flavor, or overall acceptability. In both studies, a greater $(P<0.001)$ percentage of consumers rated chops cooked to $63{ }^{\circ} \mathrm{C}$ as acceptable compared with chops cooked to $71{ }^{\circ} \mathrm{C}$. Therefore, internal cooking temperature has a greater impact on consumer eating experience than "quality grade" or ultimate $\mathrm{pH}$.

Keywords: color, consumer preference, degree of doneness, marbling, pork, ultimate pH

(C) The Author (s) 2019. Published by Oxford University Press on behalf of the American Society of Animal Science. All rights reserved. For permissions, please e-mail: journals.permissions@oup.com.

J. Anim. Sci. 2019.97:2460-2467 doi: 10.1093/jas/skz117

\section{INTRODUCTION}

Consumers use visual color and marbling (intramuscular fat) as indicators of tenderness and juiciness when evaluating pork products for purchase (Wood et al., 2004; Lonergan et al., 2007). Because consumers value color and marbling

${ }^{1}$ Corresponding author: dboler2@illinois.edu

Received February 15, 2019.

Accepted April 8, 2019. when making purchasing decisions, the United States Department of Agriculture (USDA) used NPPC visual color and marbling as criteria for a proposed quality grading system where darker chops with greater marbling were valued over lighter chops with less marbling (USDA, 2017). Further, it has long been accepted that lighter colored chops have a lesser ultimate $\mathrm{pH}$ and darker colored chops have a greater ultimate $\mathrm{pH}$ (Monin and Sellier, 1985). Ultimate $\mathrm{pH}$ of pork chops was positively correlated with visual color and 
sensory tenderness (Huff-Lonergan et al., 2002). Additionally, increasing ultimate $\mathrm{pH}$ of fresh pork chops cooked to $71^{\circ} \mathrm{C}$ increased sensory tenderness and juiciness (Lonergan et al., 2007) and cooking chops to $63{ }^{\circ} \mathrm{C}$ increased sensory tenderness scores (Richardson et al., 2018). Rincker et al. (2008) reported an improvement in sensory tenderness of pork chops cooked to $62{ }^{\circ} \mathrm{C}$ compared with chops cooked to 71 or $80{ }^{\circ} \mathrm{C}$. Because of this, and because safety is not compromised, the USDA reduced the recommended endpoint temperature of pork muscle cuts, in 2011 , from 71 to $63{ }^{\circ} \mathrm{C}$ as a means of improving sensory traits and maintaining food safety. However, there are limited data on the effects of ultimate $\mathrm{pH}$ or the proposed quality grading system on consumer acceptability of pork chops cooked to the revised internal cooking temperature recommendations. Therefore, the objective was to determine the effect of "quality grade" (combination of visual color and marbling) or ultimate $\mathrm{pH}$ on consumer eating experience of pork chops cooked to different final internal temperatures. The hypothesis was that consumers would rate a greater percentage of pork chops as acceptable when graded "choice," had a greater ultimate $\mathrm{pH}$, or when cooked to $63{ }^{\circ} \mathrm{C}$ compared with chops that graded "standard," had a lesser $\mathrm{pH}$, or when cooked to 71 or $82^{\circ} \mathrm{C}$.

\section{MATERIALS AND METHODS}

Pigs from both experiments were slaughtered at commercial facilities under the supervision of the USDA Food Safety and Inspection Service. Boneless loins were purchased from those facilities and transported to the University of Illinois Meat Science Laboratory. Therefore, Institutional Animal Care and Use Committee approval was not obtained. Sensory procedures for all consumer evaluations were reviewed and approved by the University of Illinois Office for the Protection of Research Subjects.

\section{Experiment 1}

Loins used in Exp. 1 were from a commercial feeding trial that evaluated a feed additive intended to improve gut health (data not published). Pork quality measurements were conducted on 14-d-aged loins including: visual color, visual marbling, subjective firmness, instrumental color, and ultimate $\mathrm{pH}$. There were no differences between treatments for any loin quality trait $(P \geq 0.23)$. Therefore, dietary treatments were disregarded during the allocations of loins to treatments for sensory evaluation. Loins were categorized using the previously proposed USDA quality grades based on NPPC visual color and marbling scores. Chops were classified as "choice" when NPPC visual color score was $\geq 3$ and visual marbling score was $\geq 2$ or "standard" when either NPPC color or marbling score minimums were not met (USDA, 2017). Candidate loins were targeted to have an ultimate $\mathrm{pH}$ range of 5.65 to 5.80 (category $\mathrm{C}$ as defined by Lonergan et al., 2007). Due to the number of loins available in each quality grade, the $\mathrm{pH}$ range was slightly altered to an ultimate $\mathrm{pH}$ range of 5.64 to 5.76. In total, 24 loins that graded "choice" and 24 loins that graded "standard" were selected for consumer sensory evaluation (Table 1). Loins were cut into $2.54 \mathrm{~cm}$ thick chops using a push-feed style Treif Puma slicer (Treif model 700 F; Treif, Oberlahr, Germany). Chops were vacuum packaged and stored at $-20^{\circ} \mathrm{C}$ until sensory evaluation. Two chops from each loin were randomly assigned to ending cooking temperatures of 63 or $71^{\circ} \mathrm{C}$.

\section{Experiment 2}

Loins used in Exp. 2 were from the same population of pigs described previously by Richardson et al. (2018). The objective of that experiment was to determine effects of ultimate $\mathrm{pH}$ and visual color on trained sensory panel traits of pork loin chops cooked to an internal temperature of $63{ }^{\circ} \mathrm{C}$. Loins, described by Richardson et al. (2018), were sorted into different $\mathrm{pH}$ bins based on historical $\mathrm{pH}$ categories described by Lonergan et al. (2007): category A > 5.95, category $\mathrm{B} \geq 5.80$ to 5.95 , category $\mathrm{C} \geq 5.65$ to 5.80 , category $\mathrm{D} \geq 5.50$ to 5.65 , and category $\mathrm{E}<5.50$. Loins were sorted according to the ultimate $\mathrm{pH}$ of the loin muscle assessed at 1-d postmortem. Loins were selected from categories A and $\mathrm{B}$ to represent the high $\mathrm{pH}$ treatment group and from categories $\mathrm{D}$ and $\mathrm{E}$ to represent the low $\mathrm{pH}$ treatment group. High $\mathrm{pH}$ loins had an ultimate $\mathrm{pH}$ range of 5.88 to 6.23 (Table 2). Low $\mathrm{pH}$ loins had an ultimate $\mathrm{pH}$ range of 5.36 to 5.56. Twenty-six loins were selected from the high $\mathrm{pH}$ treatment group and 26 loins were selected for the low $\mathrm{pH}$ treatment group. Loins were aged until 16-d postmortem and were then cut into $2.54 \mathrm{~cm}$ thick chops, vacuum-packaged, and stored at $-20{ }^{\circ} \mathrm{C}$ until further analysis. Three chops from each loin were randomly assigned to 1 of 3 ending cooking temperatures: 63,71 , and $82{ }^{\circ} \mathrm{C}$.

\section{Consumer Sensory Panels}

All consumer sensory panels were conducted at the University of Illinois Meat Science Laboratory. Flyers and e-mails were sent out through the 
Table 1. Effects of proposed USDA quality grade categories on chop quality characteristics

\begin{tabular}{|c|c|c|c|c|}
\hline \multirow[b]{2}{*}{ Item } & \multicolumn{2}{|c|}{ Quality grade $^{1}$} & \multirow[b]{2}{*}{ SEM } & \multirow[b]{2}{*}{$P$-value } \\
\hline & Choice & Standard & & \\
\hline \multicolumn{5}{|l|}{ Subjective evaluations $^{2}$} \\
\hline Visual color & 3.3 & 3.3 & 0.07 & 0.66 \\
\hline Visual marbling & 2.4 & 1.4 & 0.07 & $<0.0001$ \\
\hline Subjective firmness & 2.8 & 2.5 & 0.16 & 0.36 \\
\hline \multicolumn{5}{|l|}{ Instrumental color ${ }^{3}$} \\
\hline Lightness, L* & 50.60 & 50.71 & 0.64 & 0.91 \\
\hline Redness, $a^{*}$ & 8.27 & 8.25 & 0.32 & 0.96 \\
\hline Yellowness, b* & 3.00 & 2.80 & 0.20 & 0.50 \\
\hline Ultimate $\mathrm{pH}$ & 5.70 & 5.70 & 0.01 & 0.92 \\
\hline Extractible lipid, $\%$ & 2.62 & 1.52 & 0.14 & $<0.0001$ \\
\hline
\end{tabular}

${ }^{1}$ Choice chops had visual color scores $\geq 3$ and visual marbling scores $\geq 2$. Standard chops were those that did not meet the minimum criteria for either visual color or visual marbling.

${ }^{2} \mathrm{NPPC}$ color using the 1999 standards, half point scale where $1=$ visually palest and $6=$ visually darkest; NPPC marbling using the 1999 standards where $1=$ visually the least marbling and $6=$ visually the most marbling; NPPC firmness using the 1991 standard where $1=$ softest and $6=$ firmest.

${ }^{3} \mathrm{~L}^{*}$ measures darkness to lightness (greater $\mathrm{L}^{*}$ indicates a lighter color), $\mathrm{a}^{*}$ measures redness (greater $\mathrm{a}^{*}$ value indicates a redder color), and $\mathrm{b}^{*}$ measures yellowness (greater $b^{*}$ value indicates a more yellow color).

university to assemble a pool of consumers for both experiments. Willing participants were given a link to fill out an online survey informing investigators of their age, gender, race, and education level (Tables 3 and 4). Along with demographic information, time availability was record for each participant. Once the online survey closed, participants were assigned panels. Participants were only allowed to participate once on each experiment, but some consumers did participate on both experiments. Panels were scheduled during 7 evaluation days. Each day included seven 20-min sensory panels that used up to 6 panelists per sensory session. Frozen chops were placed into boxes according to their assigned serving day. Chops for both experiments were removed the freezer $24 \mathrm{~h}$ prior to each panel. Water baths were warmed using an immersion heater sous-vide device (ANOVA Precision Cooker, Anova Applied Electronics, San Francisco, CA) and set to 63 or $71{ }^{\circ} \mathrm{C}$ for Exp. 1 and 63,71 , or $82^{\circ} \mathrm{C}$ for Exp. 2. Chops were cooked using a sous-vide approach because the method is becoming increasingly more popular among consumers (Baldwin, 2012). An hour and a half before each panel started, chops were removed from the refrigerator (still in the vacuum-sealed bag) and placed into their assigned water bath. Water bath temperatures were monitored and adjusted when needed throughout the cooking process. Upon arrival, participants completed a wavier
Table 2. Effects of ultimate $\mathrm{pH}$ categories on $16 \mathrm{~d}$ loin quality characteristics

\begin{tabular}{lcccc}
\hline \hline & \multicolumn{2}{c}{ Ultimate $\mathrm{pH}^{1}$} & & \\
\cline { 2 - 4 } Item & High & Low & SEM & $P$-value \\
\hline Ultimate $\mathrm{pH}$ & 6.00 & 5.52 & 0.02 & $<0.0001$ \\
Subjective evaluations ${ }^{2}$ & & & & \\
$\quad$ Visual color & 3.8 & 3.1 & 0.10 & $<0.0001$ \\
$\quad$ Visual marbling & 2.8 & 2.2 & 0.14 & $<0.01$ \\
$\quad$ Subjective firmness & 3.3 & 3.2 & 0.11 & 0.62 \\
Instrumental color ${ }^{3}$ & & & & \\
$\quad$ Lightness, L* & 42.00 & 47.77 & 0.64 & $<0.0001$ \\
$\quad$ Redness, a* & 9.05 & 9.52 & 0.19 & 0.08 \\
$\quad$ Yellowness, ${ }^{*}$ & 3.16 & 5.65 & 0.25 & $<0.0001$ \\
\hline
\end{tabular}

${ }^{1}$ High ultimate $\mathrm{pH}$ range of 5.88 to 6.23 , low ultimate $\mathrm{pH}$ ranged 5.36 to 5.56 measured on day 1 postmortem.

${ }^{2} \mathrm{NPPC}$ color using the 1999 standards, half point scale where $1=$ visually palest and $6=$ visually darkest; NPPC marbling using the 1999 standards where $1=$ visually the least marbling and 6 = visually the most marbling; NPPC firmness using the 1991 standard where $1=$ softest and $6=$ firmest.

${ }^{3} \mathrm{~L}^{*}$ measures darkness to lightness (greater $\mathrm{L}^{*}$ indicates a lighter color), $\mathrm{a}^{*}$ measures redness (greater $\mathrm{a}^{*}$ value indicates a redder color), and $b^{*}$ measures yellowness (greater $b^{*}$ value indicates a more yellow color).

form informing them of the task they agreed to complete. After forms were signed and all participants were present, a monitor welcomed the group. A brief instruction session preparing participants for the sensory panel included a description of the sensory booths and what they needed to do with the material they were provided and instructions familiarizing each panelist with the evaluation forms. Once all consumer participants arrived, packaged chops were removed from the water bath. Chops were removed from their packages and final internal temperatures were measured using a meat thermometer. Chops were then placed in a sample sizer and sliced into $1 \mathrm{~cm} \times 1 \mathrm{~cm} \times 2.54 \mathrm{~cm}$ samples. Two pieces from each chop were placed into a small plastic cups with a numbered lid.

Panelists were seated in a breadbox style sensory booth room under red light to mask color differences among the samples. Panelist was provided a writing utensil, napkin, water, unsalted crackers, and an empty cup for any non-swallowed samples. A 9-point Likert-type scoring system was used where 1 was extremely tough, extremely dry, extremely bland, and unacceptable, 5 was neutral for tenderness, juiciness, flavorful, and acceptability, and 9 was extremely tender, extremely juicy, extremely flavorful, and acceptable. For Exp. 1, each panelist was served 4 samples (Choice, $63{ }^{\circ} \mathrm{C}$; Choice, $71^{\circ} \mathrm{C}$; Standard, $63{ }^{\circ} \mathrm{C}$; Standard, $71^{\circ} \mathrm{C}$ ) in a randomized order. For Exp. 2, each panelist was 
Table 3. Demographic summary of participating consumers ( $n=133$ ) evaluating the effects of a proposed USDA quality grade and degree of doneness

\begin{tabular}{|c|c|c|}
\hline Characteristic & Response & Percentage of consumers \\
\hline \multicolumn{3}{|l|}{$\overline{\text { Age }}$} \\
\hline & $18-25 \mathrm{yr}$ old & 12.8 \\
\hline & $26-35 \mathrm{yr}$ old & 13.5 \\
\hline & $36-55$ yr old & 42.9 \\
\hline & $56-75$ yr old & 30.1 \\
\hline & $76 \mathrm{yr}$ old or older & 0.8 \\
\hline \multicolumn{3}{|l|}{ Ethnic origin } \\
\hline & Asian/Pacific Islander & 10.5 \\
\hline & Black or African American & 1.5 \\
\hline & Hispanic or Latino & 0.8 \\
\hline & Other & 3.8 \\
\hline & White & 83.5 \\
\hline \multicolumn{3}{|l|}{ Gender } \\
\hline & Female & 55.6 \\
\hline & Male & 44.4 \\
\hline \multicolumn{3}{|l|}{$\begin{array}{l}\text { Education } \\
\text { level }\end{array}$} \\
\hline & $\begin{array}{l}\text { Completed an advanced } \\
\text { or graduate degree }\end{array}$ & 42.9 \\
\hline & Some graduate school & 12.0 \\
\hline & $\begin{array}{l}\text { Completed an under- } \\
\text { graduate degree }\end{array}$ & 27.8 \\
\hline & Some college & 15.0 \\
\hline & High school diploma & 2.3 \\
\hline
\end{tabular}

served 6 samples $\left(\operatorname{High} \mathrm{pH}, 63^{\circ} \mathrm{C}\right.$; High $\mathrm{pH}, 71^{\circ} \mathrm{C}$; High $\mathrm{pH}, 82^{\circ} \mathrm{C}$; Low $\mathrm{pH}, 63^{\circ} \mathrm{C}$; Low $\mathrm{pH}, 71^{\circ} \mathrm{C}$; Low $\mathrm{pH}, 82^{\circ} \mathrm{C}$ ) in a randomized order. Samples were served to panelists one at a time through a small door on each of the sensory booths. Once all samples were served and evaluated, panelist exited the booth and returned the evaluation forms to the monitor.

\section{Statistical Analysis}

Data from each panel were entered into Excel (Microsoft Office, 2016) for each of the panelists using the score they provided for each sample in regards to tenderness, juiciness, flavor, and overall acceptability. The scoring was sorted into three categories. Scores 1 through 3 were considered not tender, not juicy, not flavorful, or unacceptable. Scores 4 through 6 were considered neutral for tenderness, juiciness, flavor, and overall acceptability. Scores 7 through 9 were considered tender, juicy, flavorful, and acceptable. Each experiment was treated as an independent data set, but all data were analyzed using the GLIMMIX procedure of SAS (SAS Inst. In., Cary, NC). Experiment 1 was analyzed using a model that included quality grade, degree
Table 4. Demographic summary of participating consumers $(n=131)$ evaluating the effects of loin ultimate $\mathrm{pH}$ and degree of doneness

\begin{tabular}{|c|c|c|}
\hline Characteristic & Response & Percentage of consumers \\
\hline \multicolumn{3}{|l|}{$\overline{\text { Age }}$} \\
\hline & $18-25 \mathrm{yr}$ old & 10.7 \\
\hline & $26-35 \mathrm{yr}$ old & 20.6 \\
\hline & $36-55$ yr old & 35.9 \\
\hline & $56-75 \mathrm{yr}$ old & 31.3 \\
\hline & $76 \mathrm{yr}$ old or older & 1.5 \\
\hline \multicolumn{3}{|l|}{ Ethnic origin } \\
\hline & Asian/Pacific Islander & 10.7 \\
\hline & $\begin{array}{c}\text { Black or African } \\
\text { American }\end{array}$ & 0.8 \\
\hline & Hispanic or Latino & 3.1 \\
\hline & Other & 2.3 \\
\hline & White & 83.2 \\
\hline \multicolumn{3}{|l|}{ Gender } \\
\hline & Female & 50.4 \\
\hline & Male & 49.6 \\
\hline \multicolumn{3}{|l|}{ Education level } \\
\hline & $\begin{array}{c}\text { Completed an advanced } \\
\text { or graduate degree }\end{array}$ & 38.2 \\
\hline & Some graduate school & 14.5 \\
\hline & $\begin{array}{l}\text { Completed an under- } \\
\text { graduate degree }\end{array}$ & 23.7 \\
\hline & Some college & 22.9 \\
\hline & High school diploma & 0.8 \\
\hline
\end{tabular}

of doneness, and the interaction. Experiment 2 was analyzed using a model that included $\mathrm{pH}$ category, degree of doneness, and the interaction. Panel was a random variable for both experiments. No significant interactions were detected for any parameter for either experiment. Therefore, only main effects were reported. All means were separated using the PDIFF option and were considered significantly different at $P<0.05$. Means represent the percentage of panelists that reported findings in each of the 3 scoring categories.

\section{RESULTS}

\section{Experiment 1}

Demographic summary data from Exp. 1 are provided (Table 3). White ethnic origin and ages between 36 and $55 \mathrm{yr}$ old were the majority of consumers $(83.5 \%$ and $42.9 \%$, respectively). Completed an advanced or graduate degree was the most common education level among consumers $(42.9 \%)$. Gender was slightly skewed toward female $(55.6 \%)$ compared with males $(44.4 \%)$.

Only one significant interaction $(P=0.02)$ between degree of doneness and quality grades for 
consumer overall neutral acceptability was detected. There were no differences in the percentage of choice chops rated neutral but a greater percentage of consumers rated standard chops cooked to $71^{\circ} \mathrm{C}$ as neutral compared with standard chops cooked to $63{ }^{\circ} \mathrm{C}(P<0.001)$. Quality grade had no effect $(P \geq 0.26)$ on tenderness, juiciness, flavor, or acceptability of cooked pork chops regardless of temperature (Table 5). A greater percentage $(P<0.001)$ of consumers rated chops cooked to $63^{\circ} \mathrm{C}$ to be tender $(61.27 \%)$, juicy $(61.66 \%)$, and flavorful $(32.87 \%)$ compared to chops cooked to $71^{\circ} \mathrm{C}$. Overall, $47.78 \%$ of consumers rated chops cooked to $63{ }^{\circ} \mathrm{C}$ to be acceptable $(P<0.001)$ compared with only $17.90 \%$ of consumer acceptability of chops cooked to $71{ }^{\circ} \mathrm{C}$.

\section{Experiment 2}

Demographic summary data from Exp. 2 are provided (Table 4). The majority of consumers were of white ethnic origin $(83.2 \%)$ and between the ages of 36 to $55 \mathrm{yr}$ old $(35.88 \%)$. Gender was nearly equally represented between males (49.6\%) and females (50.4\%). Completed an advanced or graduate degree was the most common education level among consumers (38.2\%).

There were no interactions $(P \geq 0.19)$ between ultimate $\mathrm{pH}$ and degree of doneness for any consumer sensory trait (Table 6). A greater $(P<0.01)$ percentage of consumers rated chops with a high $\mathrm{pH}(36.07 \%)$ as juicy compared with the percentage of consumers that rated chops with a low pH (24.29\%) as juicy (Table 6). Tenderness, flavor, and overall acceptability were not influenced $(P \geq 0.13)$ by ultimate $\mathrm{pH}$.

Nearly $9 \%(8.48 \%)$ of consumers reported chops cooked to $71{ }^{\circ} \mathrm{C}$ to be not tender compared with only $0.87 \%$ of consumers rating chops cooked to $63{ }^{\circ} \mathrm{C}$ as not tender. Conversely, $81.25 \%$ of consumers rated chops cooked to $63{ }^{\circ} \mathrm{C}$ as tender. Whereas, only $49.05 \%$ of consumers rated chops cooked to $71{ }^{\circ} \mathrm{C}$ as tender.

Nearly $20 \%(19.51 \%)$ of consumers reported chops cooked to $71{ }^{\circ} \mathrm{C}$ to be not juicy compared with only $3.06 \%$ of consumers rating chops cooked to $63{ }^{\circ} \mathrm{C}$ as not juicy. Conversely, $70.61 \%$ of consumers rated chops cooked to $63{ }^{\circ} \mathrm{C}$ as juicy. Whereas, only $24.41 \%$ of consumers rated chops cooked to $71{ }^{\circ} \mathrm{C}$ as juicy.

Nearly $20 \%(17.90 \%)$ of consumers reported chops cooked to $71{ }^{\circ} \mathrm{C}$ to be not flavorful compared with only $10.23 \%$ of consumers rating chops cooked to $63{ }^{\circ} \mathrm{C}$ as not flavorful. Conversely, 39.83\% of consumers rated chops cooked to $63{ }^{\circ} \mathrm{C}$ as flavorful. Whereas, only $22.50 \%$ of consumers rated chops cooked to $71^{\circ} \mathrm{C}$ as flavorful.

Table 5. Effects of degree of doneness (DOD) and proposed USDA quality grade on consumer sensory traits of pork chops ${ }^{1,2}$

\begin{tabular}{|c|c|c|c|c|c|c|c|c|}
\hline & \multicolumn{2}{|c|}{ Quality grade ${ }^{3}$} & \multicolumn{3}{|c|}{ Degree of doneness } & \multicolumn{3}{|c|}{$P$-value } \\
\hline & Choice & Standard & $63^{\circ} \mathrm{C}$ & $71^{\circ} \mathrm{C}$ & SEM & Quality grade & DOD & Quality grade $\times$ DOD \\
\hline \multicolumn{9}{|c|}{ Consumer tenderness } \\
\hline Not tender & 13.07 & 13.08 & 6.34 & 24.98 & 3.62 & 0.99 & $<0.001$ & 0.40 \\
\hline Neutral & 42.28 & 41.76 & 32.13 & 52.60 & 3.36 & 0.91 & $<0.01$ & 0.08 \\
\hline Tender & 38.59 & 39.60 & 61.27 & 20.66 & 4.53 & 0.83 & $<0.001$ & 0.26 \\
\hline \multicolumn{9}{|l|}{ Consumer juiciness } \\
\hline Not juicy & 13.53 & 10.45 & 4.75 & 26.80 & 3.68 & 0.36 & $<0.001$ & 0.30 \\
\hline Neutral & 45.57 & 45.23 & 33.46 & 57.90 & 3.16 & 0.94 & $<0.001$ & 0.79 \\
\hline Juicy & 32.69 & 34.48 & 61.66 & 13.71 & 4.48 & 0.71 & $<0.001$ & 0.93 \\
\hline \multicolumn{9}{|l|}{ Consumer flavor } \\
\hline Not flavorful & 22.92 & 18.80 & 15.68 & 27.03 & 3.28 & 0.26 & $<0.01$ & 0.24 \\
\hline Neutral & 52.24 & 55.63 & 50.73 & 57.12 & 3.15 & 0.44 & 0.15 & 0.79 \\
\hline Flavorful & 23.66 & 22.30 & 32.87 & 15.37 & 3.29 & 0.72 & $<0.001$ & 0.20 \\
\hline \multicolumn{9}{|c|}{ Overall acceptability } \\
\hline Not acceptable & 10.45 & 10.78 & 6.07 & 17.90 & 2.96 & 0.91 & $<0.001$ & 0.22 \\
\hline Neutral & 56.79 & 56.71 & 45.63 & 67.22 & 3.45 & 0.99 & $<0.001$ & 0.02 \\
\hline Acceptable & 27.79 & 27.54 & 47.78 & 13.77 & 4.06 & 0.96 & $<0.001$ & 0.11 \\
\hline
\end{tabular}

${ }^{1}$ Values reported are a percentage of responses for each of the main effects.

${ }^{2}$ Consumers used a 9-point Likert-type score system where scores 1 through 3 were considered not tender, not juicy, not flavorful, or unacceptable. Scores 4 through 6 were consider neutral for tenderness, juiciness, flavor, and overall acceptability. Scores 7 through 9 were considered tender, juicy, flavorful, and acceptable.

${ }^{3}$ Choice chops had visual color scores $\geq 3$ and visual marbling scores $\geq 2$. Standard chops were those that did not meet the minimum criteria for either visual color or visual marbling. 
Table 6. Effects of degree of doneness (DOD) and ultimate $\mathrm{pH}$ on consumer sensory traits of pork chops ${ }^{1,2}$

\begin{tabular}{|c|c|c|c|c|c|c|c|c|c|}
\hline & \multicolumn{2}{|c|}{ Ultimate $\mathrm{pH}^{3}$} & \multicolumn{4}{|c|}{ Degree of doneness } & \multicolumn{3}{|c|}{$P$-value } \\
\hline & High & Low & $63^{\circ} \mathrm{C}$ & $71^{\circ} \mathrm{C}$ & $82^{\circ} \mathrm{C}$ & SEM & $\mathrm{pH}$ & DOD & $\mathrm{pH} \times \mathrm{DOD}$ \\
\hline \multicolumn{10}{|c|}{ Consumer tenderness } \\
\hline Not tender & 4.28 & 6.32 & $0.87^{\mathrm{c}}$ & $8.48^{b}$ & $17.00^{\mathrm{a}}$ & 3.16 & 0.36 & $<0.001$ & 0.87 \\
\hline Neutral & 34.80 & 36.06 & $18.89^{\mathrm{c}}$ & $40.87^{\mathrm{b}}$ & $50.64^{\mathrm{a}}$ & 3.67 & 0.73 & $<0.001$ & 0.50 \\
\hline Tender & 56.46 & 52.81 & $81.25^{\mathrm{a}}$ & $49.05^{\mathrm{b}}$ & $29.52^{\mathrm{c}}$ & 4.64 & 0.37 & $<0.001$ & 0.42 \\
\hline \multicolumn{10}{|l|}{ Consumer juiciness } \\
\hline Not juicy & 14.17 & 16.99 & $3.06^{\mathrm{c}}$ & $19.51^{\mathrm{b}}$ & $44.82^{\mathrm{a}}$ & 5.11 & 0.41 & $<0.001$ & 0.26 \\
\hline Neutral & 38.45 & 41.81 & $27.11^{\mathrm{b}}$ & $51.19^{\mathrm{a}}$ & $43.52^{\mathrm{a}}$ & 3.33 & 0.35 & $<0.01$ & 0.19 \\
\hline Juicy & 36.07 & 24.29 & $70.61^{\mathrm{a}}$ & $24.41^{\mathrm{b}}$ & $9.03^{\mathrm{c}}$ & 4.91 & $<0.01$ & $<0.001$ & 0.93 \\
\hline \multicolumn{10}{|l|}{ Consumer flavor } \\
\hline Not flavorful & 18.82 & 16.10 & $10.23^{\mathrm{c}}$ & $17.90^{\mathrm{b}}$ & $27.40^{\mathrm{a}}$ & 4.08 & 0.33 & $<0.01$ & 0.45 \\
\hline Neutral & 54.17 & 52.64 & 47.87 & 56.34 & 55.96 & 3.41 & 0.67 & 0.10 & 0.52 \\
\hline Flavorful & 21.15 & 26.07 & $39.83^{\mathrm{a}}$ & $22.50^{\mathrm{b}}$ & $13.15^{\mathrm{c}}$ & 4.59 & 0.13 & $<0.001$ & 0.44 \\
\hline \multicolumn{10}{|c|}{ Overall acceptability } \\
\hline Not acceptable & 8.49 & 9.98 & $2.77^{\mathrm{c}}$ & $9.59^{b}$ & $25.68^{\mathrm{a}}$ & 4.18 & 0.53 & $<0.001$ & 0.96 \\
\hline Neutral & 48.16 & 50.06 & $35.74^{\mathrm{b}}$ & $57.14^{\mathrm{a}}$ & $54.79^{\mathrm{a}}$ & 3.67 & 0.61 & $<0.001$ & 0.93 \\
\hline Acceptable & 36.44 & 31.87 & $61.82^{\mathrm{a}}$ & $30.61^{\mathrm{b}}$ & $16.27^{\mathrm{c}}$ & 4.62 & 0.23 & $<0.001$ & 0.95 \\
\hline
\end{tabular}

${ }^{\mathrm{a}, \mathrm{b}}$ Least square means within a row among main effects lacking a common superscript $\operatorname{differ}(P<0.05)$.

${ }^{1}$ Values reported are a percentage of responses for each of the main effects.

${ }^{2}$ Consumers used a 9-point Likert-type score system where scores 1 through 3 were considered not tender, not juicy, not flavorful, or unacceptable. Scores 4 through 6 were consider neutral for tenderness, juiciness, flavor, and overall acceptability. Scores 7 through 9 were considered tender, juicy, flavorful, and acceptable.

${ }^{3}$ High ultimate $\mathrm{pH}$ ranged from 5.88 to 6.23 , low ultimate $\mathrm{pH}$ ranged from 5.36 to 5.56 .

Nearly $10 \%(9.59 \%)$ of consumers reported chops cooked to $71{ }^{\circ} \mathrm{C}$ to be not acceptable compared with only $2.77 \%$ of consumers rating chops cooked to $63{ }^{\circ} \mathrm{C}$ as not acceptable. Conversely, $61.82 \%$ of consumers rated chops cooked to $63{ }^{\circ} \mathrm{C}$ as acceptable. Whereas, only $30.61 \%$ of consumers rated chops cooked to $71{ }^{\circ} \mathrm{C}$ as acceptable.

\section{DISCUSSION}

Fresh color and visual marbling are used as indicators of tenderness and juiciness by consumers when they are evaluate pork products for purchase (Wood et al., 2004; Lonergan et al., 2007). Because of this, the USDA proposed a quality grading system using NPPC visual color and marbling scores (USDA, 2017) as a means of providing consumers a tool to aid in selection of fresh pork chops. However, for this grading system to be successful, color and marbling need to be associated with a positive eating experience. To date, nearly all reports evaluating the relationships between color and marbling with eating experience have used trained sensory panelists rather than consumers. Further, only limited data are available to determine consumers' preferences when chops were cooked to $63^{\circ} \mathrm{C}$ rather than $71^{\circ} \mathrm{C}$.

For the present study, chops were assigned to 1 of 2 quality grade categories, choice or standard.
Consumers were unable to detect sensory tenderness, juiciness, or flavor differences between the quality grades. These results are consistent with a previous trained sensory panel study that cooked chops to $63{ }^{\circ} \mathrm{C}$. Wilson et al. (2017) reported that extractable lipid and instrumental color were independently poor predictors of sensory traits in pork loin chops cooked to $63{ }^{\circ} \mathrm{C}$. Additionally, Wilson et al. (2017) reported trained sensory panelist was unable to detect differences in tenderness or juiciness among chops categorized into "quality grades" of high, medium, and low quality grading system. If the classification system of Wilson et al. (2017) was used on the loins of the present study, then the standard loins would be "low quality" and the choice loins "medium quality."

Color and marbling are most often used as indicators of eating quality, but recent results do not support these relationships. Lowell et al. (2017) reported cook loss percentage $(r \leq|0.22|)$ and instrumental tenderness $(r \leq|0.26|)$ were not correlated with instrumental color or visual color when chops were cooked to $68{ }^{\circ} \mathrm{C}$. No instrumental or visual color parameters were moderately or strongly correlated with instrumental tenderness or cook loss in chops cooked to a range of 63 to $71{ }^{\circ} \mathrm{C}$ as described in Harsh et al. (2018). Rincker et al. (2008) reported a positive, but weak, relationship between sensory traits and marbling that only accounted for 
$13 \%$ of variation explained by those measurements with chops cooked to $71{ }^{\circ} \mathrm{C}$.

In contrast to these results, Cannata et al. (2010) reported trained sensory panelist rated chops with greater marbling $(3.56 \%)$ as more juicy and tender compared to chops with less marbling $(1.96 \%)$ of marbling when chops were cooked to $71{ }^{\circ} \mathrm{C}$. Another study reported consumers rated chops with $3 \%$ to $3.5 \%$ extractable lipid content as more tender and juicy than chops with $\leq 1 \%$ extractable lipid when chops were cooked to a $71{ }^{\circ} \mathrm{C}$ internal temperature (Brewer et al., 2001). In both studies described above, the extractable lipid levels of the "high" treatments were greater than the mean extractable lipid $(2.62 \%)$ of the "choice" quality grade used in the present study. In fact, the amount of extractable lipid of the "high" treatment group would rate as "Prime" in the proposed quality grading system.

Though the hypothesis for the present study was that chops grading choice would rate more tender, juicy, flavorful, and overall more acceptable compared to standard chops, this was not the case. One explanation for this lack of difference in eating experience is the similar color of standard and choice chops in this study. Because both color and marbling requirements must be met for chops to be labeled choice, standard chops did meet the color requirement (NPPC color score of $\geq 3$ ) but not the marbling requirement (NPPC marbling score of $\geq 2$ ). This resulted in similar color scores ad objective color readings between standard and choice chops. Future research should include prime, choice, select, and standard quality grades using the USDA proposed quality system. In today's industry, finding a well-controlled population that ranges from prime to select quality grades might prove difficult but would provide good additional information to the present study.

An additional objective of the present study was to determine the influence of ultimate $\mathrm{pH}$ on consumer perceptions of pork chop sensory traits. Previously, ultimate $\mathrm{pH}$ of pork chops was positively correlated with visual color and sensory tenderness (Huff-Lonergan et al., 2002). Additionally, increasing ultimate $\mathrm{pH}$ of fresh pork chops increased sensory tenderness and juiciness of chops cooked to $71{ }^{\circ} \mathrm{C}$ (Lonergan et al., 2007). This is similar to the present study where a greater percentage of consumers rated the high $\mathrm{pH}$ treatment juicy compared to the low $\mathrm{pH}$ treatment. However, no other consumer sensory traits were different between the $\mathrm{pH}$ treatments. Results of the present study are similar to those of Richardson et al.
(2018) who reported no differences in sensory tenderness between chops of different ultimate $\mathrm{pH}$ when chops were cooked to $63{ }^{\circ} \mathrm{C}$, until $\mathrm{pH}$ exceeded 5.95. Chops with ultimate $\mathrm{pH}$ greater than 5.95 were more tender than all other $\mathrm{pH}$ categories. However, consumers in the present study did not find pork chops from the "high" $\mathrm{pH}$ category to be more tender. In the present study, this "high" category included loins with ultimate $\mathrm{pH}$ ranging from 5.88 to 6.23 , therefore not as extreme as the high $\mathrm{pH}$ loins in the previous study.

While consumers were not able to detect differences in tenderness between $\mathrm{pH}$ treatments or quality grades, they were able to detect differences in tenderness between chops cooked to different degrees of doneness. The USDA recently changed the final internal temperature to cook whole pork muscles from 71 to $63{ }^{\circ} \mathrm{C}$ (FSIS, 2013). The pork production industry has changed over the years to an indoor commercial setting eliminating the risk of contamination via Trichinella sprilis, allowing for a lower endpoint cooking temperature (Pyburn et al., 2005). In this present study, both previously established and revised cooking temperatures were used to assess their effect on consumer sensory traits. Regardless of $\mathrm{pH}$ treatment or quality grade, consumers rated chops cooked to $63{ }^{\circ} \mathrm{C}$ more tender, juicy, flavorful, and overall acceptable compared to chops cooked to a higher degree of doneness. Rincker et al. (2008) reported, as final internal cooking temperature increases from 62 to $80{ }^{\circ} \mathrm{C}$, trained sensory tenderness and juiciness decreases from 8.56 to 6.81 and 9.85 to 6.29 , respectively. Rincker et al. (2008) also reported a linear relationship between consumer tenderness and juiciness scores and visual marbling score, in chops cooked to $71{ }^{\circ} \mathrm{C}$. However, results from the present study indicate that it is the final internal temperature that impacts overall eating experience, not quality grade (visual color and visual marbling).

Public acceptance and application of the revised cooking temperature will require both time and education. According to focus groups conducted by FSIS (1998), consumers do not regularly use meat thermometers. Other methods such as the "eye ball" method, cooking until no red or pink is inside, or until juice or fluids run clear were among the reported methods used by consumers to check their meat. Focus groups also reported that they would use a meat thermometer if it would enhance the flavor or quality of the product they were preparing. Consumers need to be educated on the importance of the meat thermometer and the ideal temperature to cook whole pork muscles. 
Font-i-Furnols and Guerrero (2014) explained that a consumer's behavior toward meat and meat products can be affected by three main factor categories: marketing, psychological, and sensory factors. Visual appearance (color and marbling) of the meat is a sensory factor that was discussed earlier. Additionally, psychological factors may include beliefs of meat that were formed by observations, information, or inferences can all influence consumer preferences (Font-i-Furnols and Guerrero, 2014). Education on proper cooking techniques and cooking temperatures of pork products, with the use of a meat thermometer, will help to ensure consumers have a positive eating experience and become a repeat consumer.

In conclusion, ultimate $\mathrm{pH}$ has little impact on consumer sensory traits except for juiciness which increases with increasing ultimate $\mathrm{pH}$. A proposed quality grade system would not guarantee superior eating experience with higher quality grades. Additionally, a lower final internal temperature of whole pork muscles will improve tenderness, juiciness, flavor, and overall consumer acceptability. Overall, ultimate $\mathrm{pH}$ and "quality grades" did not impact consumer sensory traits of pork loin chops that cooked to $63{ }^{\circ} \mathrm{C}$. Regardless of the visual color or marbling of a pork chop in the retail case, preparation of the chop by the consumer has a greater impact than the pork chop that is purchased.

\section{LITERATURE CITED}

Baldwin, D. E. 2012. Sous vide cooking: a review. Int. J. Gastron. Food Sci. 1:15-30. doi:10.1016/j.ijgfs.2011.11.002

Brewer, M. S., L. G. Zhu, and F. K. McKeith. 2001. Marbling effects on quality characteristics of pork loin chops: consumer purchase intent, visual and sensory characteristics. Meat Sci. 59:153-163. doi:10.1016/ S0309-1740(01)00065-1

Cannata, S., T. E. Engle, S. J. Moeller, H. N. Zerby, A. E. Radunz, M. D. Green, P. D. Bass, and K. E. Belk. 2010. Effect of visual marbling on sensory properties and quality traits of pork loin. Meat Sci. 85:428-434. doi:10.1016/j.meatsci.2010.02.011

Font-i-Furnols, M., and L. Guerrero. 2014. Consumer preference, behavior and perception about meat and meat products: an overview. Meat Sci. 98:361-371. doi:10.1016/j. meatsci.2014.06.025

Food Safety and Inspection Service (FSIS). 1998. Focus groups on barriers that limit consumers' use of thermometers when cooking meat and poultry products: phase on. U.S. Food and Drug Administration, FSIS, Washington, DC. http://www.fsis.usda.gov/oa/topics/focusgp.pdf (Accessed 21 December 2018.)

Food Safety and Inspection Service (FSIS). 2013. Fresh pork from farm to table. https://www.fsis.usda.gov/wps/portal/ fsis/topics/food-safety-education/get-answers/food-safetyfact-sheets/meat-preparation/fresh-pork-from-farm-totable/CT_Index (Accessed 21 December 2018.)

Harsh, B. N., D. D. Boler, S. D. Shackelford, and A. C. Dilger. 2018. Determining the relationship between early postmortem loin quality attributes and aged loin quality attributes using meta-analyses techniques. J. Anim. Sci. 96:3161-3172. doi:10.1093/jas/sky183

Huff-Lonergan, E., T. J. Baas, M. Malek, J. C. M. Dekkers, K. Prusa, and M. F. Rothschild. 2002. Correlations among selected pork quality traits. J. Anim. Sci. 80:617627. doi: $10.2527 / 2002.803617 \mathrm{x}$

Lonergan, S. M., K. J. Stalder, E. Huff-Lonergan, T. J. Knight, R. N. Goodwin, K. J. Prusa, and D. C. Beitz. 2007. Influence of lipid content on pork sensory quality within pH classification. J. Anim. Sci. 85:1074-1079. doi:10.2527/ jas.2006-413.

Lowell, J. E., M. F. Overholt, B. N. Harsh, C. A. Stahl, A. C. Dilger, and D. D. Boler. 2017. Relationships among early postmortem loin quality and aged loin and pork chop quality characteristics between barrows and gilts. Transl. Anim. Sci. 1:607-619. doi:10.2527/tas2017.0074

Monin, G., and P. Sellier. 1985. Pork of low technological quality with a normal rate of muscle $\mathrm{pH}$ fall in the immediate post-mortem period: the case of the Hampshire breed. Meat Sci. 13:49-63. doi:10.1016/S0309-1740(85)80004-8

Pyburn, D. G., H. R. Gamble, E. A. Wagstrom, L. A. Anderson, and L. E. Miller. 2005. Trichinae certification in the United States pork industry. Vet. Parasitol. 132:179-183. doi:10.1016/j.vetpar.2005.05.051

Richardson, E. L., B. Fields, A. C. Dilger, and D. D. Boler. 2018. The effects of ultimate $\mathrm{pH}$ and color on sensory traits of pork loin chops cooked to a medium-rare degree of doneness. J. Anim. Sci. 96:3768-3776. doi:10.1093/jas/ sky258

Rincker, P. J., J. Killefer, M. Ellis, M. S. Brewer, and F. K. McKeith. 2008. Intramuscular fat content has little influence on the eating quality of fresh pork loin chops. J. Anim. Sci. 86:730-737. doi:10.2527/jas.2007-0490

USDA. 2017. U.S. grade standards: pork carcasses. https://www. regulations.gov/document?D=AMS_FRDOC_0001-1640 (Accessed 12 January 2019.)

Wilson, K. B., M. F. Overholt, C. M. Shull, C. Schwab, A. C. Dilger, and D. D. Boler. 2017. The effects of instrumental color and extractable lipid content on sensory characteristics of pork loin chops cooked to a mediumrare degree of doneness. J. Anim. Sci. 95:2052-2060. doi:10.2527/jas.2016.1313

Wood, J. D., G. R. Nute, R. I. Richardson, F. M. Whittington, O. Southwood, G. Plastow, R. Mansbridge, N. da Costa, and K. C. Chang. 2004. Effects of breed, diet and muscle on fat deposition and eating quality in pigs. Meat Sci. 67:651-667. doi:10.1016/j.meatsci.2004.01.007 